\title{
Nutrient intake, digestibility, growth performance and carcass characteristics of Farta sheep fed urea-treated rice straw supplemented with graded levels of dried Sesbania sesban leaves
}

Lamrot Tekliye, Yeshambel Mekuriaw, Bimrew Asmare* and Fantahun Mehret

\begin{abstract}
Background: The experiment was conducted using twenty-five Farta sheep to investigate the response of supplementing dried Sesbania sesban leaves (SSL) on feed intake, digestibility, growth performance and carcass characteristics of Farta sheep fed urea-treated rice straw. Twenty-five male Farta sheep with initial body weight of $18.9 \pm 1.7 \mathrm{~kg}$ ( mean \pm SD) were used in randomized complete block design with five replications. The treatments were $0 \mathrm{~g}$ Sesbania sesban leaves (SSL) (control $T_{1}$ ), $100 \mathrm{~g} \mathrm{SSL}\left(T_{2}\right), 200 \mathrm{~g} \mathrm{SSL}\left(T_{3}\right), 300 \mathrm{~g} \mathrm{SSL}\left(T_{4}\right)$ and $400 \mathrm{~g} \mathrm{SSL}\left(T_{5}\right)$. The experiment lasted 90 days of growth and 7 days of digestibility period. All experimental sheep were given urea-treated rice straw ad libitum as basal diet. Chemical composition of diets and refusals, feed intake, digestibility of dry matter and nutrients, carcass yield and quality were recorded. All collected data were analyzed using general linear model (GLM) procedure of SAS version 9.1.3. Means were separated using Duncan's multiple-range test. Correlations among nutrient intakes, weight gain and digestibility of nutrients were analyzed using Pearson linear correlation test.

Results: Results showed that supplementation of SSL significantly increased $(P<0.001)$ total dry matter, crude protein and organic matter intakes. Supplementation of SSL improved the digestibility of dry matter, organic matter $(P<0.05)$, crude protein $(P<0.01)$. Final body weight $(P<0.01)$, average daily gain and feed conversion efficiency $(P<0.001)$ for $T_{5}$ were higher for supplement groups, while sheep fed sole UTRS $\left(T_{1}\right)$ lost body weight. Slaughter weight $(P<0.01)$, empty body weight $(P<0.01)$ and hot carcass weight $(P<0.001)$ increase with increase in the level of supplementation. Dressing percentage on slaughter BW basis and EBW basis was higher $(P<0.05)$ for $T_{5}$ than control. The partial budge analysis result indicated that sheep fed UTRS alone had the lowest net return ( $-92.22 \mathrm{ETB})$, while sheep supplemented with $400 \mathrm{~g} \mathrm{SSL}\left(T_{5}\right)$ had better net return (144.6 ETB) with marginal rate (1.7) compared to the other supplemented treatments.
\end{abstract}

Conclusion: From the study it could be concluded that SSL could serve as alternative CP supplement in ureatreated-based crop residues feeding of growing Farta sheep to improve the biological performance and economic feasibility in the study area.

Keywords: Digestibility, Farta sheep, Feed intake, Sesbania sesban, Urea-treated rice straw

*Correspondence: limasm2009@gmail.com

Department of Animal Production and Technology, Bahir Dar University,

P. O. Box. 5501, Bahir Dar, Ethiopia 


\section{Background}

Livestock production is an important component of the farming systems in all parts of Ethiopia and plays a vital role in the livelihood of many people. Sheep and goats are widely reared in a crop-livestock farming systems and are distributed across different agroecological zones of Ethiopia. They require smaller investments, have shorter production cycles and greater environmental adaptability and hence have a unique niche in smallholder agriculture. Although diverse sheep and goat resources are found in Ethiopia, their productivity is low mainly because of inadequate year-round nutrition, in terms of both quantity and quality [1]. Livestock in general and sheep in particular are getting their feed from natural pasture and crop residues. Among the crop residues, rice straw has become involved as livestock feed. Rice straw is abundantly available crop residues in most tropical and subtropical countries and commonly used as a diet for ruminants, although feeding only rice straw does not provide enough nutrients to the ruminants to maintain high production levels due to the low nutritive value of this highly lignified material. By treating rice straw with urea intake, degradability and growth can be enhanced, compared to feeding untreated rice straw alone [2].

Most investigations in animal nutrition have been conducted on supplementation of poor-quality roughages with concentrates [3]; however, concentrate feeds comprised of especially grains and oil seeds are expensive and highly valued as human food [4]. Moreover, agroindustrial by-products are inaccessible and unaffordable to smallholder farmers; hence, alternative supplementary feedstuffs produced on-farm other than commercial concentrates are very essential. In this regard, strategic supplementation of unexploited, cheap, less competitive and year-round available and easily accessible protein sources like Sesbania sesban could be a feasible alternative to mitigate protein deficiency in poor-quality feeds during periods of feed scarcity. Therefore, the current study was conducted to evaluate the effects of graded levels of Sesbania sesban leaves supplementation on feed intake, digestibility, live weight change and carcass characteristics of Farta sheep fed urea-treated rice straw as basal diet.

\section{Methods}

\section{Description of the experimental area}

The sheep feeding trial was conducted at Zenzelma Campus of Bahir Dar University which is located between latitude and longitude of $11^{\circ} 37 \mathrm{~N} 37^{\circ} 27 \mathrm{E}$ coordinates and an elevation of 1900 masl. The average daily minimum and maximum temperatures were $7^{\circ} \mathrm{C}$ and $29^{\circ} \mathrm{C}$, respectively. The average annual rainfall was $1445 \mathrm{~mm}$.
Experimental animals, their management and treatments Twenty-five male Farta sheep with average age of 1 year and initial body weight of $18.9 \pm 1.7 \mathrm{~kg}$ (mean \pm SD) were purchased from Debre Tabor town. The age of the sheep was determined by dentition and information from the owners. The experimental animals were ear-tagged for identification. The sheep quarantined for 15 days to observe incidence of any disease. During this quarantine period, each animal was treated against internal (albendazole) and external (ivermectin) parasites. Animals were continuously observed for incidence of any ill health and disorders during the experimental period.

The experiment was conducted in a randomized complete block design with five treatments and five replications based on their initial body weight. Treatment 1 was the control, where animals received only urea-treated rice straw basal diet ad libitum. The remaining treatments involved supplementation of dried Sesbania sesban leaves at $100 \mathrm{~g}$ (treatment 2), $200 \mathrm{~g}$ (treatment 3), $300 \mathrm{~g}$ (treatment 4) and $400 \mathrm{~g}$ (treatment 5) per day on top of urea molasses-treated rice straw basal diet.

Rice straw was chopped to about 5-10 cm size to make it easily compacted. Four $\mathrm{kg}$ of urea dissolved with 80 liter water was used to treat $100 \mathrm{~kg}$ of rice straw. The straw was treated with a solution prepared on a plastic sheet on the floor, mixed thoroughly and rubbed with hand to ensure proper penetration of the solution. The treated straw was well trampled and compacted batch by batch until filled to the bag capacity. After filling the bag was tightened carefully and loaded by straw on top. The ensiled straw was left unopened for 21 days for proper treatment to occur. At the end of 21 days, the bag was opened and a portion of the straw was taken daily and ventilated overnight to remove residual ammonia before offering to the animals.

\section{Digestibility, feed intake and body weight change}

Digestibility trial was conducted before the commencement of the actual feeding trial. Sheep were fitted (harnessed) with fecal collection bags. Feces were collected and recorded every morning; $20 \%$ of representative samples were taken and frozen at $-20^{\circ} \mathrm{C}$ and pooled over the collection period for each animal. At the end of the collection period, each sample was mixed and dried at $60{ }^{\circ} \mathrm{C}$ for $72 \mathrm{~h}$. Apparent digestibility of nutrients was calculated as the proportion of the difference between nutrient consumed and nutrient in feces to nutrient consumed.

The feeding trial lasted for 90 days. During feed trial, daily feed offered and refusals were collected from each treatment throughout the experimental period. Daily mean feed intake was measured as differences between offered and refused feeds. The sheep was offered 
ad libitum hay, at 20\% refusal. Feed refusal samples were taken daily per animal during the feeding and digestion period, pooled on treatment basis, and used for chemical analysis.

Initial body weight of animals was determined by taking the mean of two consecutive weights, and subsequent body weight measurements were taken at 10-day interval. Final body weight was taken at the end of the experiment. Average daily body weight gains (ADG) were calculated as difference between final and initial weights divided by the number of feeding days. According to [5, 6], feed conversion efficiency of experimental animals was determined by dividing the average daily $\mathrm{BW}$ gain to the amount of feed consumed.

\section{Carcass parameters}

Carcass parameters were analyzed at the end of the experiment. Blood, heart, liver, kidney, tongue, reticulorumen, omasum abomasums, hind gut (small and large intestine) and internal fat (kidney, omental and mesenteric) were weighed and considered as edible offal components. Head (without tongue), skin, testicle, penis, feet, gut content, bladder, spleen and lung with trachea were recorded and considered as non-edible offal components. Empty body weight (EBW) was calculated as the difference between slaughter weight (SW) and gut content. Dressing percentage (DP) was calculated as proportion of HCW to SW and EBW. Both the right and left halves were cut between the 12th and 13th ribs perpendicular to the backbone to measure the cross section of the rib eye area (REA).

\section{Chemical composition analysis}

The representative samples of daily feed offers, refusals and feces were taken. Dry matter content was determined by oven-drying samples at $105^{\circ} \mathrm{C}$. The crude protein (CP) content determined as $N^{*} 6.25$. Ash was determined by igniting the samples in muffle furnaces at $550{ }^{\circ} \mathrm{C}$ over night. Neutral detergent fiber (NDF), acid detergent fiber (ADF) and acid detergent lignin (ADL) were analyzed following recommendation [7].

\section{Statistical analysis}

Data on feed intake, digestibility, weight gain and carcass parameter analysis were subjected to general linear model (GLM) procedures SAS 9.3.1. Means were separated using Duncan's multiple-range test. Correlation between nutrient intakes, weight gain and digestibility of nutrients were analyzed using Pearson correlation procedure.

\section{Model}

$$
Y_{i j}=\mu+T_{i}+B_{j}+E_{i j}
$$

where $Y_{i j}$ is the response variable (the observation in $\mathbf{j}_{\text {th }}$ block and $i_{\text {th }}$ treatment), $\mu$ overall mean, $T_{i}$ treatment effect, $B_{j}$ block effect, and $E_{i j}$ random error.

\section{Partial budget analysis}

The difference in selling and purchasing price was considered as total return (TR). A net return (NR) was calculated by subtracting TVC from the total return (TR).

\section{Results}

\section{Chemical composition of treatment feeds}

The chemical composition of experimental feeds and refusals is shown in Table 1 . The CP content of Sesbania sesban leaf was much higher than urea-treated rice straw. But the fiber fraction (NDF, ADF and ADL) in Sesbania sesban was clearly lower than the basal feed.

Table 1 Chemical composition of experimental feeds and urea-treated rice straw refusals

\begin{tabular}{|c|c|c|c|c|c|c|c|}
\hline Parameters & DM & OM & Ash & $\mathrm{CP}$ & NDF & ADF & $A D L$ \\
\hline \multicolumn{8}{|l|}{ Feed offer } \\
\hline UTRS & 88 & 88.30 & 11.7 & 10.2 & 73.3 & 64.4 & 25.0 \\
\hline SSL & 89 & 84.45 & 15.55 & 26.4 & 27.5 & 20.2 & 10.0 \\
\hline \multicolumn{8}{|c|}{ UMTRS refusals } \\
\hline$T_{1}$ & 88 & 89.23 & 10.77 & 8.08 & 75.11 & 67.22 & 26.66 \\
\hline$T_{2}$ & 88 & 90.23 & 9.77 & 9.92 & 75.33 & 65.44 & 28.88 \\
\hline$T_{3}$ & 89 & 88.23 & 11.77 & 8.02 & 76.44 & 65.44 & 28.88 \\
\hline$T_{4}$ & 88 & 89.34 & 10.66 & 9.0 & 76.11 & 65.22 & 26.66 \\
\hline$T_{5}$ & 88 & 89.34 & 10.66 & 9.70 & 75.11 & 66.22 & 27.77 \\
\hline
\end{tabular}

$A D F$ acid detergent fiber, $A D L$ acid detergent lignin, $C P$ crude protein, DM dry matter, NDF neutral detergent fiber, OM organic matter, UTRS urea-treated rice straw UMTRS urea molasses-treated rice straw, SSL Sesbania sesban leaves 


\section{Feed and nutrient intake}

The feed DM and nutrient intake of Farta sheep fed ureatreated rice straw supplemented with Sesbania sesban are presented in Table 2 . The mean daily DM intake of UTRS for the control was higher $(P<0.001)$ than the supplemented treatments, but the contrary was true for TDMI. There was difference $(P<0.01)$ in TDMI among treatments, and TDMI increased as the level of SSL increased. The intake of $\mathrm{CP}$ and $\mathrm{OM}$ was increased $(P<0.001)$ in the order $T_{5}>T_{4}>T_{3}>T_{2}>T_{1}$. Intake of the NDF $(P<0.001)$ and $\operatorname{ADF}(P<0.01)$ increased with the level of Sesbania sesban supplementation.

\section{Nutrient digestibility}

The apparent digestibility of DM, OM, CP, NDF, ADF and ADL in Farta sheep fed urea-treated rice straw and supplemented with Sesbania sesban is presented in Table 3. Apparent digestibility of DM, OM and CP for sheep supplemented sheep was higher $(P<0.01)$ than control group. NDF and ADF digestibility $(P<0.01)$ increases with increase in the level of Sesbania sesban.

\section{Body weight change and feed conversion efficiency}

Body weight change parameters of Farta sheep fed ureatreated rice straw supplemented with Sesbania sesban are presented in Table 4. Final body weight was significant $(P<0.01)$ in the supplemented groups. Average daily gain, body weight change and feed conversion efficiency $(P<0.001)$ were increased with supplementation level increased.

\section{Carcass characteristics}

Carcass characteristics of Farta sheep fed urea-treated rice straw and supplemented with dried Sesbania sesban leaves are presented in Table 5. Supplemented sheep had higher value slaughter weight (SW), empty body weight $(\mathrm{EBW})(P<0.01)$ and hot carcass weight $(\mathrm{HCW})$ $(P<0.001)$ than sheep fed sole urea-treated rice straw. Dressing percentage as slaughter weight (DPSW) and

Table 2 Daily feed and nutrient intake of Farta sheep fed urea-treated rice straw supplemented with Sesbania sesban

\begin{tabular}{|c|c|c|c|c|c|c|}
\hline \multirow[t]{2}{*}{ Intake (g/day) } & \multicolumn{6}{|c|}{ Treatment feeds } \\
\hline & $T_{1}$ & $T_{2}$ & $T_{3}$ & $T_{4}$ & $T_{5}$ & SL \\
\hline Basal (UTRS) DMI & $696.00^{a}$ & $691.33^{\mathrm{a}}$ & $640.56^{b}$ & $631.41^{b}$ & $615.72^{b}$ & $* * *$ \\
\hline SSL DMI & - & $100^{d}$ & $200^{c}$ & $300^{b}$ & $400^{a}$ & $* * *$ \\
\hline Total DMI & $696.00^{e}$ & $796.00^{d}$ & $840.56^{c}$ & $931.41^{b}$ & $1015.72^{a}$ & $* * *$ \\
\hline DM intake (\%BW) & $3^{b}$ & $3.1^{a b}$ & $3.2^{a b}$ & $3.4^{a b}$ & $3.6^{\mathrm{a}}$ & $*$ \\
\hline Total OMI & $536.72^{d}$ & $611.17^{c}$ & $620.10^{c}$ & $717.21^{b}$ & $768.4^{\mathrm{a}}$ & $* * *$ \\
\hline Total CPI & $69.59^{e}$ & $98.27^{d}$ & $114.98^{c}$ & $148.39^{b}$ & $169.46^{\mathrm{a}}$ & $* * *$ \\
\hline Total NDFI & $508.70^{b c}$ & $536.42^{a b}$ & $496.16^{c}$ & $552.84^{\mathrm{a}}$ & $564.37^{a}$ & $* * *$ \\
\hline Total ADFI & $447.24^{b}$ & $465.53^{a b}$ & $462.06^{a b}$ & $469.5^{\mathrm{ab}}$ & $474.08^{a}$ & $* *$ \\
\hline Total ADLI & $201.40^{a b}$ & $208.80^{a}$ & $190.48^{b}$ & $212.49^{a}$ & $212.87^{a}$ & $* *$ \\
\hline
\end{tabular}

$T_{1}=$ UMTRS, $T_{2}=$ UTRS + $100 \mathrm{~g} \mathrm{SS} \mathrm{DM,} T_{3}=$ UMTRS + $200 \mathrm{~g} \mathrm{SS} \mathrm{DM,} T_{4}=$ UMTRS + $300 \mathrm{~g} \mathrm{SS} \mathrm{DM,} T_{5}=$ UMTRS + $400 \mathrm{~g}$ SS DM, UMTRS urea molasses-treated rice straw, SSL Sesbania sesban leaves, SEM standard error of mean, $S L$ significance level

abc Means with different superscripts in a row are significantly different at ${ }^{* * *}(P<0.001) ;{ }^{* *}(P<0.01) ;{ }^{*}(P<0.05)$

Table 3 Dry matter and nutrient digestibility of Farta sheep fed urea-treated rice straw and supplemented with dried Sesbania sesban leaves

\begin{tabular}{|c|c|c|c|c|c|c|}
\hline \multirow[t]{2}{*}{ Digestibility } & \multicolumn{6}{|c|}{ Treatment } \\
\hline & $T_{1}$ & $T_{2}$ & $T_{3}$ & $T_{4}$ & $T_{5}$ & SL \\
\hline DM & $56.5^{b}$ & $65.4^{\mathrm{ab}}$ & $65.8^{a b}$ & $67^{a}$ & $67^{a}$ & * \\
\hline $\mathrm{OM}$ & $59.7^{\mathrm{b}}$ & $67.7^{\mathrm{ab}}$ & $68.3^{a b}$ & $69.7^{a b}$ & $70.6^{a}$ & $*$ \\
\hline$C P$ & $63.8^{b}$ & $65^{b}$ & $69.02^{a b}$ & $72.44^{\mathrm{a}}$ & $73.02^{a}$ & $* *$ \\
\hline NDF & $49.6^{c}$ & $54.5^{b}$ & $60.3^{b}$ & $63.9^{a b}$ & $78.4^{a}$ & $* *$ \\
\hline ADF & $53.1^{b}$ & $53.4^{b}$ & $59.7^{b}$ & $63.5^{\mathrm{ab}}$ & $81.1^{\mathrm{a}}$ & $* *$ \\
\hline $\mathrm{ADL}$ & $47.9^{b}$ & $52^{b}$ & $55.2^{b}$ & $61^{a b}$ & $76.3^{a}$ & $*$ \\
\hline
\end{tabular}

$D M$ dry matter, $C P$ crude protein, NDF neutral detergent fiber, $A D F$ acid detergent fiber, $A D L$ acid detergent lignin, $O M$ organic matter, $S L$ significance level, $N S$ nonsignificant, $T_{1}$ (control) $=$ UTRS, $T_{2}=$ UTRS $+100 \mathrm{~g} \mathrm{SSL}, T_{3}=\mathrm{UTRS}+200 \mathrm{~g} \mathrm{SSL}, T_{4}=\mathrm{UTRS}+300 \mathrm{SSL}, T_{5}=\mathrm{UTRS}+400 \mathrm{~g} \mathrm{SSL}$

ab Means in the same row with different superscript differ significantly at ${ }^{* *} P<0.01 ;{ }^{*} P<0.05$ 
Table 4 Body weight change of Farta sheep fed urea treatment rice straw supplemented with graded leaves of dried Sesbania sesban leaves

\begin{tabular}{|c|c|c|c|c|c|c|}
\hline \multirow[t]{2}{*}{ Parameters } & \multicolumn{6}{|c|}{ Treatments } \\
\hline & $T_{1}$ & $T_{2}$ & $T_{3}$ & $T_{4}$ & $T_{5}$ & SL \\
\hline Initial body weight (kg) & $19.18^{\mathrm{a}}$ & $18.56^{\mathrm{a}}$ & $18.54^{\mathrm{a}}$ & $19.08^{\mathrm{a}}$ & $18.16^{\mathrm{a}}$ & ns \\
\hline Final body weight (kg) & $17.44^{c}$ & $19.46^{b c}$ & $19.54^{b c}$ & $21.40^{\mathrm{ab}}$ & $22.22^{\mathrm{a}}$ & ** \\
\hline Body weight change $(\mathrm{kg})$ & $-1.74^{c}$ & $0.90^{\mathrm{b}}$ & $1.00^{\mathrm{b}}$ & $2.32^{\mathrm{ab}}$ & $4.06^{\mathrm{a}}$ & $* * *$ \\
\hline ADG (g/day) & $-19.33^{c}$ & $10.00^{b}$ & $11.11^{\mathrm{b}}$ & $25.77^{\mathrm{ab}}$ & $45.11^{\mathrm{a}}$ & $* * *$ \\
\hline FCE (g ADG/g TDMI) & $-0.028^{c}$ & $0.012^{\mathrm{b}}$ & $0.014^{b}$ & $0.027^{\mathrm{a}}$ & $0.044^{\mathrm{a}}$ & $* * *$ \\
\hline
\end{tabular}

NS nonsignificant, $A D G$ average daily gain, $F C E$ feed conversion efficiency

abc Means with different superscripts in a row are significantly different at ${ }^{* *}(P<0.001)$; ${ }^{* *}(P<0.01)$

Table 5 Carcass characteristics of Farta sheep fed urea-treated rice straw and supplemented with dried Sesbania sesban leaves

\begin{tabular}{|c|c|c|c|c|c|c|}
\hline \multirow[t]{2}{*}{ Carcass characteristics } & \multicolumn{6}{|c|}{ Treatment } \\
\hline & $\overline{T_{1}}$ & $T_{2}$ & $T_{3}$ & $T_{4}$ & $T_{5}$ & $\mathrm{SL}$ \\
\hline SW (kg) & $17.52^{b}$ & $19.5^{\mathrm{ab}}$ & $19.6^{\mathrm{ab}}$ & $21.5^{\mathrm{a}}$ & $22.60^{\mathrm{a}}$ & $* *$ \\
\hline EBW (kg) & $12.70^{c}$ & $13.6^{\mathrm{bc}}$ & $14.30^{b c}$ & $16.2^{\mathrm{ab}}$ & $17.0^{\mathrm{a}}$ & $* *$ \\
\hline $\mathrm{HCW}(\mathrm{kg})$ & $6.48^{c}$ & $6.73^{c}$ & $7.15^{b c}$ & $8.4^{\mathrm{ab}}$ & $9.0^{\mathrm{a}}$ & $* * *$ \\
\hline \multicolumn{7}{|l|}{ Dressing percentage } \\
\hline SW basis (\%) & $36.7^{b}$ & $37.46^{\mathrm{ab}}$ & $37.70^{\mathrm{ab}}$ & $39.0^{\mathrm{ab}}$ & $40.0^{\mathrm{a}}$ & * \\
\hline EBW basis (\%) & $48.3^{b}$ & $50.0^{\mathrm{ab}}$ & $51.15^{\mathrm{a}}$ & $51.3^{\mathrm{a}}$ & $51.8^{\mathrm{a}}$ & * \\
\hline $\operatorname{REA}\left(\mathrm{cm}^{2}\right)$ & $8.41^{\mathrm{a}}$ & $8.43^{\mathrm{a}}$ & $8.8^{\mathrm{a}}$ & $9.7^{\mathrm{a}}$ & $10.8^{\mathrm{a}}$ & NS \\
\hline
\end{tabular}

SW slaughter weight, EBW empty body weight, HCW hot carcass weight, REA rib eye muscle area, SL significance level, NS nonsignificant

$a, b, c$ Means with the same letter in the same row are not significantly different, ${ }^{* *} P<0.01,{ }^{*} P<0.05$

dressing percentage as empty body weight (DPEBW) bases were significant $(P<0.05)$ and better for $T_{5}$. Rib eye muscle area (REA) was not affected by supplementation.

\section{Edible offal components}

The edible offal components of the carcass of yearling Farta sheep fed urea-treated rice straw and supplemented with Sesbania sesban are presented in Table 6. Liver, kidney, reticulorumen, hind gut, $(P<0.05)$ and testicles $(P<0.01)$ were higher in $T_{5}$ compared to $T_{1}$. Lower total edible offal (TEO) was recorded in $T_{1}$ and higher in $T_{5}$. Blood, heart, tongue, omasum abomasum, omental and mesenteric fat and kidney were not affected by supplementation. Skin, lung with trachea and bladder were higher $(P<0.05)$ for $T_{5}$ compared to other treatments. Spleen was higher $(P<0.01)$ for $T_{5}$ compared to $T_{1}$.

\section{Non-edible offal components}

The non-edible offal components of the carcass obtained from the slaughter of yearling Farta sheep fed a basal diet of UTRS and supplemented with graded levels of dried Sesbania sesban leaf are presented in Table 7. The non-edible offal components such as skin, lung with trachea and bladder were significantly higher $(P<0.05)$ for $T_{5}$. Head without tongue, feet, esophagus, gull bladder with bile and gut content were not significantly $(P>0.05)$ affected by supplementation. Head without tongue, penis, feet, esophagus, gull bladder with bile and gut content were not affected by supplementation.

\section{Partial budget analysis}

The partial budget analysis result of Farta sheep fed urea-treated rice straw and supplemented with dried Sesbania sesban leaves is presented in Table 8. Sheep fed sole urea-treated rice straw had a negative net return (-92.22 ETB/sheep). Among all treatment groups, sheep supplemented with the highest level of Sesbania sesban leaves $\left(T_{5}\right)$ returned a higher net return as compared to the other levels of supplementation and the control treatment. The net return from the supplemented treatments was 21.36, 73.76, 135.16 and 144.58 ETH/head for $T_{2}, T_{3}, T_{4}$ and $T_{5}$. 
Table 6 Edible offal components of Farta sheep fed urea-treated rice straw and supplemented with dried Sesbania sesban leaves

\begin{tabular}{|c|c|c|c|c|c|c|}
\hline \multirow[t]{2}{*}{ Edible offal } & \multicolumn{6}{|c|}{ Treatment } \\
\hline & $T_{1}$ & $T_{2}$ & $T_{3}$ & $T_{4}$ & $T_{5}$ & SL \\
\hline Blood & $718.1^{\mathrm{a}}$ & $769.3^{\mathrm{a}}$ & $771.1^{\mathrm{a}}$ & $785.83^{\mathrm{a}}$ & $807.9^{\mathrm{a}}$ & NS \\
\hline Heart & $71.6^{\mathrm{a}}$ & $73.1^{\mathrm{a}}$ & $84.5^{\mathrm{a}}$ & $95.2^{\mathrm{a}}$ & $100.5^{\mathrm{a}}$ & NS \\
\hline Liver & $213.8^{b}$ & $256.1^{\mathrm{ab}}$ & $278^{\mathrm{ab}}$ & $291.1^{\mathrm{a}}$ & $322.2^{\mathrm{a}}$ & $*$ \\
\hline Kidney & $53.5^{\mathrm{b}}$ & $55.5^{\mathrm{ab}}$ & $62.4^{\mathrm{ab}}$ & $62.6^{a}$ & $63.9^{\mathrm{a}}$ & * \\
\hline Tongue & $80.4^{\mathrm{a}}$ & $85.67^{\mathrm{a}}$ & $86.42^{\mathrm{a}}$ & $86.47^{\mathrm{a}}$ & $89.3^{\mathrm{a}}$ & NS \\
\hline Reticulorumen & $435.5^{b}$ & $487.2^{b}$ & $501.2^{\mathrm{b}}$ & $575.8^{\mathrm{ab}}$ & $660.6^{\mathrm{a}}$ & * \\
\hline Omasum abomasum & $160.2^{\mathrm{a}}$ & $161.4^{\mathrm{a}}$ & $174.1^{\mathrm{a}}$ & $186.0^{\mathrm{a}}$ & $187.7^{\mathrm{a}}$ & NS \\
\hline Hind gut & $420.3^{b}$ & $522.7^{\mathrm{ab}}$ & $509^{\mathrm{ab}}$ & $591.4^{\mathrm{ab}}$ & $610.4^{\mathrm{a}}$ & $*$ \\
\hline Testicles & $101.4^{b}$ & $119.1^{b}$ & $182.8^{\mathrm{ab}}$ & $210.2^{\mathrm{a}}$ & $239.3^{\mathrm{a}}$ & $* *$ \\
\hline Kidney fat & $11^{\mathrm{a}}$ & $12.3^{\mathrm{a}}$ & $12.5^{\mathrm{a}}$ & $13.8^{\mathrm{a}}$ & $16.9^{\mathrm{a}}$ & NS \\
\hline Omental and mesenteric fat & $32.13^{\mathrm{a}}$ & $36.78^{\mathrm{a}}$ & $43.43^{\mathrm{a}}$ & $56.5^{\mathrm{a}}$ & $62.48^{\mathrm{a}}$ & NS \\
\hline Total edible offal $(\mathrm{kg})$ & $2.31^{\mathrm{b}}$ & $2.62^{\mathrm{ba}}$ & $2.72^{\mathrm{ba}}$ & $3.01^{\mathrm{a}}$ & $3.04^{\mathrm{a}}$ & * \\
\hline Total usable product (kg) & $10.26^{c}$ & $10.82^{b c}$ & $11.67^{\mathrm{bc}}$ & $13.2^{\text {ba }}$ & $14.17^{\mathrm{a}}$ & $* *$ \\
\hline Total usable product (\%SW) & $59.43^{\mathrm{a}}$ & $59.7^{\mathrm{a}}$ & $61.08^{\mathrm{a}}$ & $61.2^{\mathrm{a}}$ & $64.48^{\mathrm{a}}$ & NS \\
\hline
\end{tabular}

SL significance level, NS nonsignificant

$\mathrm{a}, \mathrm{b}$ Means with the same letter in the same row are not significantly different, ${ }^{*} P<0.05,{ }^{*} P<0.01$

Table 7 Non-edible offal components of Farta sheep fed urea-treated rice straw and supplemented with dried Sesbania sesban leaves

\begin{tabular}{|c|c|c|c|c|c|c|}
\hline \multirow[t]{2}{*}{ Non-edible offal } & \multicolumn{6}{|c|}{ Treatment } \\
\hline & $T_{1}$ & $T_{2}$ & $T_{3}$ & $T_{4}$ & $T_{5}$ & SL \\
\hline Head without tongue (kg) & $1.21^{\mathrm{a}}$ & $1.24^{\mathrm{a}}$ & $1.43^{\mathrm{a}}$ & $1.4^{\mathrm{a}}$ & $1.58^{\mathrm{a}}$ & NS \\
\hline Skin (g) & $1.68^{\mathrm{b}}$ & $1.93^{\mathrm{ab}}$ & $1.94^{\mathrm{ab}}$ & $2.1^{\mathrm{ab}}$ & $2.43^{\mathrm{a}}$ & $*$ \\
\hline Penis (g) & $41.7^{\mathrm{a}}$ & $49.93^{\mathrm{a}}$ & $52.25^{\mathrm{a}}$ & $55.3^{\mathrm{a}}$ & $56.55^{\mathrm{a}}$ & NS \\
\hline Feet (g) & $514.13^{\mathrm{a}}$ & $515.10^{\mathrm{a}}$ & $531.03^{\mathrm{a}}$ & $560.10^{\mathrm{a}}$ & $553.25^{\mathrm{a}}$ & NS \\
\hline Lung with trachea (g) & $262.15^{\mathrm{b}}$ & $305.5^{\mathrm{ab}}$ & $305.6^{\mathrm{ab}}$ & $315.4^{\mathrm{ab}}$ & $380.55^{\mathrm{a}}$ & $*$ \\
\hline Spleen (g) & $21.28^{c}$ & $24.65^{c}$ & $29.55^{b c}$ & $35.85^{\mathrm{ab}}$ & $39.48^{a}$ & $* *$ \\
\hline Esophagus (g) & $33^{\mathrm{a}}$ & $33.39^{\mathrm{a}}$ & $35.88^{\mathrm{a}}$ & $39.75^{a}$ & $39.15^{\mathrm{a}}$ & NS \\
\hline Gull bladder with bile (g) & $5.5^{\mathrm{a}}$ & $5.75^{\mathrm{a}}$ & $10.7^{\mathrm{a}}$ & $8.03^{\mathrm{a}}$ & $10.88^{a}$ & NS \\
\hline Bladder & $21.25^{b}$ & $26.43^{\mathrm{ab}}$ & $23.28^{\mathrm{ab}}$ & $38.6^{\mathrm{ab}}$ & $54.48^{\mathrm{a}}$ & * \\
\hline Gut content (kg) & $5.35^{\mathrm{a}}$ & $4.68^{\mathrm{a}}$ & $4.85^{\mathrm{a}}$ & $4.53^{\mathrm{a}}$ & $4.44^{\mathrm{a}}$ & NS \\
\hline Total non-edible offal (kg) & $6.278^{b}$ & $6.279^{b}$ & $7.01^{\mathrm{ab}}$ & $8.06^{\mathrm{ab}}$ & $8.7^{\mathrm{a}}$ & * \\
\hline
\end{tabular}

SL significance level, NS nonsignificant

a, $b$ Means with the same letter in the same row are not significantly different, ${ }^{*} P<0.05 ;{ }^{*} P<0.01$

\section{Discussion}

\section{Chemical composition of treatment feeds}

The observed CP (10.17\%) content of urea-treated rice straw in the current study was higher than $7.1 \%$ and $5.5 \%$ $[8,9]$. This difference might be due to the stage of rice harvested and the time and season differences. The CP and ash composition of the refusal UTRS was reduced; however, NDF, ADF and ADL were increased compared to UTRS offer. This confirms the ability of sheep to select better nutritive value and palatable parts. Protein supplements are feedstuffs containing more than 20\% CP [10]. Based on this Sesbania sesban leaves were recognized as protein source and it demonstrated its greatest value when supplemented with low-quality roughage like the rice straw used in this experiment. The value of $\mathrm{CP}$ content observed in the current study was higher than $23.9 \%$ and $23.34[11,12]$, respectively, and comparable to $26.8 \%, 26.37 \%, 27.5 \%$ and $25.3 \%$ [13-16], respectively.

The NDF and ADF values of Sesbania sesban leaves in this study comparable [15] (28.7\% NDF and 23.6\% ADF), 
Table 8 Partial budget analysis of Farta sheep fed natural urea-treated rice straw and supplemented with dried Sesbania sesban

\begin{tabular}{|c|c|c|c|c|c|}
\hline \multirow[t]{2}{*}{ Variables } & \multicolumn{5}{|c|}{ Treatments } \\
\hline & $\mathrm{T} 1$ & $\mathrm{~T} 2$ & T3 & T4 & T5 \\
\hline Number of animals & 5 & 5 & 5 & 5 & 5 \\
\hline Purchasing price of sheep (ETB/head) & 650 & 650 & 650 & 650 & 650 \\
\hline Total basal diet consumed (Kg/head) & 62.22 & 62.64 & 54.24 & 56.84 & 55.42 \\
\hline Total supplement consumed (Kg/head) & - & 9 & 18 & 27 & 36 \\
\hline Total feed consumed (Kg/head) & 62.22 & 71.64 & 72.24 & 83.84 & 91.42 \\
\hline Cost of basal diet (ETB/head) & 62.22 & 62.64 & 54.24 & 56.84 & 55.42 \\
\hline Cost of supplement (ETB/head) & - & 36 & 72 & 108 & 144 \\
\hline Total feed cost (ETB/head) & 62.22 & 98.64 & 126.24 & 164.84 & 199.42 \\
\hline Gross income (selling price of sheep) (ETB) & 620 & 770 & 850 & 950 & 994 \\
\hline Total return (ETB) & -30 & 120 & 200 & 300 & 344 \\
\hline Net return (ETB) & -92.22 & 21.36 & 73.76 & 135.16 & 144.58 \\
\hline$\triangle T V C$ & - & 36.42 & 64.02 & 102.62 & 137.2 \\
\hline$\Delta \mathrm{NI}$ & - & 113.6 & 166 & 227.4 & 236.8 \\
\hline $\operatorname{MRR}((\triangle \mathrm{NI} / \Delta T V C))$ & - & 3.1 & 2.3 & 2.2 & 1.7 \\
\hline
\end{tabular}

higher than the values [13] (19.3\% NDF and 15.5\% ADF), [12] (25.8\% NDF and 17.5\% ADF) [16] (21.23\% NDF and $18.04 \% \mathrm{ADF})$ and lower than the values [17] (39.9\% NDF and $29.9 \%$ ADF). ADL content of Sesbania sesban (10\%) in this study was comparable to $9.8 \%$ [16] and higher than $4 \%, 4.1 \%, 7.5 \%, 5.5 \%$ and indicated by $[12,13,15,17]$, respectively. Generally, all the above differences in nutritional composition of Sesbania sesban may be attributed to differences in accession, stage of plant growth, cutting frequency and harvesting regimen, drying process, season, environment, soil type and fertility status, parts of the plant (leafs, twigs, whole forage and green pods) included during feeding and chemical analysis and due to the environmental conditions in which the plant grows.

\section{Feed and nutrient intake}

The UTRS DM intake decreases in supplement groups as compared to the control. This might be due to the substitution effect of SSL and its high nutrient content, which might have satisfied the nutrient requirement of the experimental sheep without additional UTRS DM intake. The supplement DM intake of $\mathrm{T}_{2}, \mathrm{~T}_{3}, \mathrm{~T}_{4}$ and $\mathrm{T}_{5}$ was $12.6,23.8,32.2$ and $38.4 \%$ of total dry matter intake, respectively. [18] indicated that if the level of supplementation is $<30-40 \%$ of the DM intake of the ani$\mathrm{mal}$, there is an increase in the intake of the basal diet, which is contrary to what has been noted in this study. Therefore, such contradictory results reported by different researchers might be due to the amount of supplement, nutrient content and ratio given to the animals. Total DM intakes increase with increase in the level of supplementation. This might be due to the fact that supplementation might have created a favorable rumen environment resulting in enhanced fermentation of the basal roughage and thus increased microbial protein synthesis, rate and extent of digestion which resulted in better DM and nutrient intakes. The total DM intake noted in this study was higher than values of $711 \mathrm{~g} / \mathrm{head} /$ day reported for Kaffa sheep [15] and comparable to 856-979 g/head/ day reported for Hararghe highland sheep [19]. Values of the CP intake in this study were higher than the values that ranged from 54.23 to $111.98 \mathrm{~g} /$ day reported [15] and 53.26 to $62.97 \mathrm{~g} /$ day reported [12, 20, 21]. The higher intake of NDF and ADF in the supplemented group could mainly be a contribution attributed to the fiber content of supplement.

\section{Apparent digestibility of DM and nutrients}

Apparent digestibility of DM and OM was better for supplement groups. This is in agreement with report of McDonald et al. [10] who noted that addition of dietary protein in the supplement has increased protein availability to rumen microorganisms to speed up the digestion process. However, the control was grouped under low digestibility which could be due to lower $\mathrm{CP}$ and higher fiber content of UTRS. Contrary to the present study, $[22,23]$ reported nonsignificant difference in the apparent digestibility of the same parameters among the supplemented and control treatments, which could be an attribute of the types of supplement used. In the current study, DM digestibility in supplement groups comparable to $66.6-68.6 \%$ observed by Worku et al. [15] and slightly 
lower 65-70\% reported [13] for Kaffa sheep and Arsi Bale sheep, respectively. CP digestibility was better for higher supplemented (300 g and $400 \mathrm{~g} \mathrm{SSL}$ ) groups. Higher values than the current finding, [15] reported CP digestibility of $85.8 \%$ in Kaffa sheep, and lower result (67.9\%) of CP digestibility was reported by [14] for Tigray local sheep.

\section{Body weight change and feed conversion efficiency}

In the current study, sheep in the control group lost weight $(1.74 \mathrm{~kg})$. Body weight loss of sheep in $T_{1}$ indicated that UTRS used in this study was unable to provide sufficient energy for maintenance requirement even it had enough CP for maintenance requirement. [24] reported that sheep fed on poor-quality roughages alone are forced to mobilize energy and protein from body tissue reserves, leading to weight loss. Similarly, [9, 25] reported loss of body weight in sheep fed urea-treated rice straw and natural pasture grass hay alone, respectively. Average daily gain attained in this study for $T_{5}$ was higher than yearling Menz sheep (33.4-35.7 g/day) fed teff straw supplemented with sole Sesbania sesban [26] and lower than $103 \mathrm{~g} /$ day for sheep fed diet containing $300 \mathrm{~g} /$ day Sesbania sesban foliage [27] and $75.71 \mathrm{~g} /$ day for Abergelle rams supplemented with $300 \mathrm{~g} /$ day DM SSL [12]. Generally, differences among treatments in ADG and FCE observed in this study are consistent with similar differences in intake and digestibility of DM and nutrients.

\section{Carcass characteristics}

In this study for slaughter weight, empty body weight and hot carcass weight were better for supplemented treatments than the control treatment, which is consistent with that observed for ADG. Hot carcass weight in this trail was comparable with 5.55-12.4, 9.23-9.8 6.979.30 and 6.4-10.1 kg for Kaffa, Washera, Arsi Bale and Farta sheep reported by different authors [9, 13, 15, 25], respectively. However, it was heavier in other studies for Wogera sheep and Farta sheep breeds [28, 29]. Dressing percentage as a proportion of slaughter BW and EBW was better for higher level (400 g SSL) of supplemented treatments than the control treatment. As opposed to the current findings, various studies reported dressing percentages calculated on empty body weight basis as having no significant difference between supplemented and nonsupplemented animals [9]. The dressing percentage (on EBW bases) values of the current study were comparable with the average dressing percentages of tropical sheep (40-50\%) reported by William et al. [30].

Rib eye area (REA) was not different among treatments. Similarly, Hailu et al. [9] reported that different levels of concentrate in the diet had no impact on rib eye muscle area. Contrary to this in $[15,28]$ report, supplementation had a significant effect on the rib eye muscle area. The value obtained for rib eye area (REA) in this study was comparable to the $8.1-11.9 \mathrm{~cm}^{2}$ values noted [25] and lower than 7.4-12.6 $\mathrm{cm}^{2}$ [29] for the same breed. Generally, the variations in carcass traits in this study and previous studies may be due to variations in initial weight and supplement feeds used for the experiment. In agreement with this, [10] noted that nutrition, age, sex, genetics, season and other related factors affect the growth and carcass traits of animals.

\section{Edible and non-edible offal components}

Supplemented treatments had better edible offal components compared to the control $T_{1}$. This might be due to high metabolic activities of the organs and high intake of protein from supplemented sheep. This is supported by Kirton et al. [31] that reported dietary status has an impact on the production efficiency of offal. The nonsignificant differences in most of the organs could be linked with organs being early maturing and consequently being little affected by dietary treatments [31]. The increase in liver weight with supplementation might be related to the storage of reserve substances such as glycogen with supplementation [32]. Lower total edible offal (TEOC) was recorded in the control group than supplemented groups of sheep. This was in agreement with various studies [9, $15,19,25,33]$ that reported heavier TEOC in supplemented sheep than the non-supplemented sheep.

The difference in slaughter weight also reflected in the weights of non-edible offal. In the current study, the nonedible offal components such as skin, lung with trachea and bladder show better result for $T_{5}$. Significant differences were observed in the weight of skin linked was better growth of hair following better feeding regime as a result of supplementation. The other non-edible offal components such as head without tongue, feet, esophagus, gull bladder with bile and gut content were not affected by supplementation. Offal components rich in bone and/or having low metabolic activity (head and feet) varied slightly with diet [31]. Gall bladder with bile also has nonsignificant difference between treatments, which might be due to lower intake of energy to stimulate liver for secretion of bile to emulsify fat and neutralize nutrient coming from stomach. The decreasing trend of gut content with increasing Sesbania sesban level might be contributed to the expected higher rate of digestion and faster passage rate of the diet through the digestive tract due to consumption of more digestible feed. However, animals on UTRS are forced to fill their gut with less digestible roughage and have proportionally bigger gut content. This result was also in agreement with the views [7, 34]; non-supplemented animals fill their gut with less digestible roughage which would be retained in the gut 
for a long time to be degraded by rumen microorganisms. In this study total non-edible offal was highest for supplemented sheep than sheep fed on sole urea-treated rice straw. The heavier TEOC and TNEOC in supplemented sheep than the non-supplement ones suggest that most of the edible and non-edible offal components were not fully grown at the beginning of this study and were able to respond to supplementation.

\section{Partial budget analysis}

The difference in net return was in a similar trend with their weight gain, i.e., loss of 92.22 ETB per animal was observed for the control treatment because weight loss was recorded. The marginal rate of return in this study was 3.1, 2.3, 2.2 and 1.7 for $T_{2}, T_{3}, T_{4}$ and $T_{5}$, respectively. This indicates that to attain required BW by supplement feeding, each additional unit of 1 ETB increment per sheep to purchase supplement feed resulted in a profit of 3.1 ETB for $T_{2,2.3}$ ETB for $T_{3,2.2}$ ETB for $T_{4}$ and 1.7 ETB for $T_{5}$, respectively. The result achieved in the present study was higher than 1.07-1.15 [12]. This may be the variations in purchasing and selling price of sheep, variations in sheep breeds used and differences in basal diet and supplements used in different experiments. Supplementation of sheep (400 g/head/day on DM basis) had more satisfactory daily BW gain $(45.11 \mathrm{~g} /$ day), highest NI (144.6 ETB), highest NI (236.8 ETB) but lowest MRR (1.7) compared to other treatments. In this study, supplementation with $T_{5}$ improved body weight change of sheep and correspondingly increased the net income from the sale of sheep at the end of the feeding trial. Therefore, among the supplemented treatments, $T_{5}$ was found to be more profitable considering the net return and marginal rate of return.

\section{Conclusion}

Supplementation of Farta sheep with Sesbania sesban leaves increased the total dry matter, crude protein and organic matter intakes. Supplementation with SSL also significantly improved apparent digestibility of nutrients, average daily gain, feed conversion efficiency and carcass characteristics. Hence, in the present study, it was concluded that supplementation of UTRS with $400 \mathrm{~g} /$ day SSL is biologically efficient, potentially profitable and socially acceptable level for growing Farta sheep. As SSL was higher in $\mathrm{CP}$ content, high performance could be expected from feeding high level of dried SSL. So, further investigation is recommended by combining Sesbania sesban leaves with another good energy source basal diet feed.

\section{Abbreviations}

EBW: empty body weight; BW: body weight; ETB: Ethiopian birr; HC: hot carcass; HCW: hot carcass weight; TVC: total variable cost.

\section{Authors' contributions}

$L T, Y M$ and BA contributed to research proposal writing, data collection, data analysis, data interpretation and article writing. FM contributed in research data collection, data analysis, data interpretation and article writing. All authors read and approved the final manuscript.

\section{Authors' information \\ Lamrot is a Lecturer of Animal Production currently teaching and conduct- ing research in animal production and productivity improvement in Ethiopia. Yeshambel is an Associate Professor of Animal Feeds and Nutrition, currently teaching and conducting research in the area of animal feeds and feeding, animal production and productivity improvement in Ethiopia. Bimrew is an Associate Professor of Animal Feeds and Nutrition, currently teaching and con- ducting research in the area of animal feeds and feeding, animal production and productivity improvement in Ethiopia. Fentahun is a Lecturer of Biotech- nology in Animal Production, currently teaching and conducting research in animal production and productivity improvement in Ethiopia.}

\section{Acknowledgements}

The authors would like to acknowledge Bahir Dar University for funding this research and Debre Berhan Agricultural Research Center Animal Nutrition laboratory for assisting in sample feed and fecal analysis.

\section{Competing interests}

The authors declare that they have no competing interests.

\section{Availability of data and materials}

The datasets used and/or analyzed during the current study are available from the corresponding author on request.

\section{Consent for publication}

Not applicable.

\section{Ethical approval and consent to participate}

A consent agreement has been confirmed from group discussants used in the current study.

\section{Funding}

Not applicable.

\section{Publisher's Note}

Springer Nature remains neutral with regard to jurisdictional claims in published maps and institutional affiliations.

Received: 14 September 2018 Accepted: 15 October 2018

Published online: 26 October 2018

\section{References}

1. Tibbo M. Productivity and health of indigenous sheep breeds and crossbreds in the Central Ethiopian highlands. Faculty of Medicine and Animal Science Department of Animal Breeding and Genetics. Ph.D. Dissertation. Swedish University of Agricultural Sciences. 2006.

2. Wanapat M, Polyrach S, Boonnop K, Mapato C, Cherdthong A. Effect of treating rice straw with urea and calcium hydroxide upon intake, digestibility, rumen fermentation and milk yield of dairy cows. Livest Sci. 2009;2009(125):238-43

3. Mekoya A. Multipurpose fodder trees in Ethiopia; Farmers' perception, constraints to adoption and effects of long-term supplementation on sheep performance. Ph.D. thesis, Wageningen University, Wageningen, The Netherlands. 2008.

4. Ayenew A, Tamir B, Melaku S. Feed intake, digestibility and live weight change of lambs fed Finger millet (Eleusine coracana) straw 
supplemented with Atella, noug seed (Guizotia abyssinica) cake and their mixtures. Agric Trop Subtrop. 2012;45(3):105-11.

5. Gülten K, Rad F, Kindir M. Growth performance and feed conversion efficiency of Siberian Sturger o juveniles (Acipenser baeri) reared in concentrate ways. Turk J Vet Anim Sci. 2000;2000(24):439.

6. Brown L, Hindmarsh R, Mcgregor R. Dynamic agricultural book three. 2nd ed. Sydney: McGraw-Hill Book Company; 2001.

7. Van Soest PJ. Nutritional ecology of ruminants. 2nd ed. London: Cornell University Press; 1994

8. Derso T. On-farm evaluation of urea treated rice straw and rice bran supplementation on feed intake, milk yield and composition of Fogera cows, North Western Ethiopia. A Thesis Submitted to the Department of Animal Science and Technology School of Graduate Studies, Bahir dar Universitiy. 2009.

9. Hailu A, Melaku S, Tamir B, Tassew A. Body weight and carcass characteristics of Washera sheep fed urea treated rice straw supplemented with graded levels of concentrate mix. Livest Res Rural Dev. 2011;23(8).

10. McDonald P, Edwards RA, Greenhalgh JFD, Morgan CA, Sinclair LA, Wilkinson RG. Animal nutrition. 7th ed. England: Longman Group UK Ltd; 2010.

11. Sabra HA, Hassan SG, Mohammed MI. Effect of Sesbania sesban (Sesbania egyptiaca) Supplementation on the reproductive performances of Baladi Sheep as compared to Berseem (Egyptian clover). J Reprod Infertil. 2010;1(3):66-70

12. Tekle D, Gebru G, Hagos H, Belay S. Effect of supplementation dried Sesbania sesban leaf on performance of Abergelle rams. J Biol Agric Healthc. 2016;6(11):125-129

13. Bekele B, Mekasha S, Melaku Y. Effect of substitution of concentrate mix with Sesbania sesban on feed intake, digestibility, body weight change, and carcass parameters of Arsi-Bale sheep fed a basal diet of native grass hay. Trop Anim Health Prod. 2013. https://doi.org/10.1007/s1125 0-013-0413.

14. Hadgu H. Effect of supplementation of concentrate mixture, dried local brewery byproduct (atella), faidherbia albida and sesbania sesban on the performance of local sheep fed hay basal diet. M.Sc. thesis Presented to Haromiya University. 2014.

15. Worku A, Animut G, Urge M. Supplementing rice bran, Sesbania (Sesbania sesban) leaf and their mixtures on digestibility and performance of Kafka sheep fed native grass hay. Int J Agric Sci Res. 2015;4(3):57-66.

16. Yirdaw M, Mengistu A, Tamir B, Berhane G. Replacing cotton seed cake by dried Acacia saligna, Sesbania sesbana and Cowpea on productivity of Begait sheep in North Ethiopia. Am Eurasian J Sci Res. 2017;12(1):29-36.

17. Etana D, Tolera A, Eik LO, Ragnar S. Nutritive value of morphological fractions of Sesbania sesban and Desmodium intortum. Trop Sub-tropical Agro Ecosyst. 2011;2011(14):793-805.

18. Topps, JH. Forage legumes as protein supplement to poor quality diets in the semi-arid tropics. In: Wallance RJ, Lahlov-kassi A, editors. Rumen ecology research planning. Proceeding of a workshop held at ILRI (International Livestock Research Institute). Ethiopia: Addis Ababa; 1997;13-18 March 1995 p. 45-50.

19. Yirga H. Supplementation of concentrate mix to Hararghe Highland sheep fed a basal diet of urea treated maize Stover; effect on feed utilization, live weight change and carcass characteristics. An M.Sc. thesis presented to the school of graduate studies of Haramaya University. 2011.

20. Gulilat L, Walelign E. Evaluation of milk production performance of lactating Fogera cows fed with urea and effective micro-organisms treated rice straw as basal diet. Int J Sci Res Publ. 2017:7:111-9.

21. Gizachew A. Comparative feedlot performance of Washera and Horro sheep fed different roughag to concentrate ratio M.Sc. Thesis submitted to Haromiya University. 2012.

22. Mekuriaw Y, Urge M, Anmut G. Intake, digestibility, live weight changes and rumen parameters of Washera sheep fed mixture of low land bamboo (Oxytenanthera abyssinca) leaves and natural pasture grass hay at different ratios. Pak J Nutr. 2012;1 1(4):322-31.

23. Bonsi MLK, Osuji PO, Tuah AK. Effect of supplementing teff straw with different levels of leucaena or sesbania leaves on the degradabilities of teff straw, sesbania, leucaena, tagasaste and vernonia and on certain rumen and blood metabolites in Ethiopian Menz sheep. Anim Feed Sci Technol. 1995;52:101-29.

24. Assefa A, Animut G. Supplementation of raw, malted and heat treated grass pea (Lathyrus Sativus) grain on body weight gain and carcass characteristics of Farta sheep. Int J Soil Crop Sci. 2013;1 (1):1-6.

25. Melaku S, Peters KJ, Tegegne A. Feed intake, live weight gain and reproductive performance of Menz sheep ewes supplemented with Lablab purpures, graded levels of Leucaena pallida 1403 and Sesbania sesban 1998. Livest Prod Sci. 2004;87:131-42.

26. Manaye T, Tolera A, Zewdu T. Feed intake, digestibility and body weight gain of sheep fed Napier grass mixed with different levels of Sesbania sesban. Livest Sci. 2009;122(1):124-9.

27. Moges M, Tamir B, Yami A. The effects supplementation of grass hay with different level of brewery dried grain on feed intake digestibility and body weight gain in intact Wogera lambs. East Afr J Sci. 2008;2:105-10.

28. Dejen. M.Sc. thesis on effect of supplementation of hay with graded level of rapeseed cake and rice bran mixture on feed intake, digestibility, body weight change and carcass characteristics of Farta sheep. M.Sc. thesis. 2011.

29. Williams $C B$, Jenkins TG. A dynamic model of metabolizable energy utilization in growing and mature cattle. II. Metabolizable energy utilization for gain. J Anim Sci. 2003:81:1382-9.

30. Kirton AH, Bennet LG, Dobbie LJ, Mercer KG, Duganzich MD. Effect of sire breed, sex and growth path on carcass composition of cross-breed lambs. J Agric Res. 1995:38:105-14.

31. Hag MGEI, Shargi KMEl. Feedlot performance and carcass characteristics of local (Dhofari) and exotic (Cashmere) goats fed on a high-fibre byproducts diet supplemented with fish sardine. Rumais Livestock Research Station. Ministry of Agriculture and Fisheries. Muscat, 1996;391-395.

32. Lawrence TJ, Fowler VR. Growth of farm animals. Wallingford: CABI; 1998.

33. Defar G, Urge M. Bodyweight gain and carcass characteristics of Horro sheep fed urea treated maize husk and untreated maize husk supplemented with different levels of concentrate mix at Bako, Western Ethiopia; 2017.

34. Pond WG, Church DC, Pond KR. Basic animal nutrition and feeding. 4th ed. New York: Wiley; 1995

Ready to submit your research? Choose BMC and benefit from

- fast, convenient online submission

- thorough peer review by experienced researchers in your field

- rapid publication on acceptance

- support for research data, including large and complex data types

- gold Open Access which fosters wider collaboration and increased citations

- maximum visibility for your research: over $100 \mathrm{M}$ website views per year

At BMC, research is always in progress.

Learn more biomedcentral.com/submissions 